\title{
Rhizosphere Microbial Population of Pea Genotypes under Different Level of Aluminium
}

\author{
Mohd Talha Ansari*, Pranabjyoti Sarma, A. S. Mailappa, C. Deo, \\ A. K. Singh, L. Wangchu and B. N. Hazarika \\ College of Horticulture and Forestry, CAU, Pasighat, Arunachal Pradesh, India \\ *Corresponding author
}

\section{A B S T R A C T}

\begin{tabular}{|l|}
\hline Ke y w or d s \\
$\begin{array}{l}\text { Aluminium toxicity, } \\
\text { Soil microbial } \\
\text { population }\end{array}$ \\
\hline Article Info \\
\hline $\begin{array}{l}\text { Accepted: } \\
\text { 22 January } 2021 \\
\text { Available Online: } \\
\text { 10 February } 2021\end{array}$ \\
\hline
\end{tabular}

The investigation was conducted to examine the effects of aluminium on the soil microorganism in the rhizosphere of pea genotypes with varying Al treatment.The experiment was layout in a factorial completely randomized design with the first factor comprised of 4 pea genotypes ( 2 tolerant and 2 susceptible each) and the second factor with 3 levels of Al treatment (control, $12 \mathrm{ppm}$ and $24 \mathrm{ppm} \mathrm{Al}$ ). The classical serial dilution technique was used for isolation of total bacterial and fungal population from the soil sample by spread plate technique on appropriate media. It was observed that aluminium caused marked influence on the bacterial and fungal population in the rhizosphere of pea genotypes. The fungal population showed a marked reduction at $24 \mathrm{ppm}$ level of aluminium treatment in all genotypes except intolerant genotype (Kashi Samridhi) where an increase in the fungal population was observed. The bacterial population showed a positive relation with aluminium treatment. Low level of $\mathrm{Al}$ treatment showed an increase in the bacterial population in the rhizosphere of susceptible genotype but at a higher level of $\mathrm{Al}$ the rhizosphere of tolerant genotype had a higher bacterial population.

\section{Introduction}

Micro-organism plays a vital role in soil fertility and crop growth. High rainfall, use of acidic fertilizer and release of industrial effluents in the soil has acidified it, rendering unsuitable for cultivation of the crop. One of the consequences of soil acidification is the increase in bioavailable toxic metals in soil especially aluminium ( $\mathrm{Al})$, iron and manganese. Microorganisms continuously interact with varied inorganic ions, some of which are essential for biological functions whereas others exert inhibitory effects that limit normal development. Microbial communities in the soil can react to both natural and anthropogenic influences related to soil chemistry (Schallmach et al., 2000), the presence of different plants (Marschner $e t$ al., 2001) changes in soil moisture (Wilkinson et al., 2002) and input of toxic pollutants (Joner et al., 2001) Aluminium is a metal lacking biological functions and in this respect pertains to the non-essential class of chemical elements. The presence of toxic ions in the environment may select for the 
appearance of tolerant microbial variants possessing genetic determinants which confer resistance to the poisonous compounds (Slawson et al., 1992). Although the toxic effects of high $\mathrm{Al}$ concentrations on plants have been known for a long time back (Hartwell and Pember, 1918) and a large number of investigations into the effects of high Al concentrations on cultivated plants, very few studies concerning the influence of Al concentration on free-living soil microorganisms has been conducted. The few microbiological works on this topic were mostly carried out in marginal fields. This neglect is surprising, given the importance of free-living soil bacteria and fungi. It was therefore the aim of this investigation to examine effects of aluminium on the soil micro-organism of pea genotypes with varying $\mathrm{Al}$ treatment.

\section{Materials and Methods}

The experiment was layout in a factorial completely randomized design with the first factor comprised of 4 pea genotypes viz. Two tolerant genotypes (Kashi Samrath and Kashi Samridhi) were collected from ICAR-IIVR, Varanasi and two susceptible genotypes Azad Pea-3 (CSAUA\&T, Kanpur) and Matar Ageta-7 (PAU, Ludhiana) and the second factor comprised of 3 levels of $\mathrm{Al}$ treatment(control,12 ppm and $24 \mathrm{ppm}$ ). The Al tolerance of pea genotypes was determined based on morphological parameters using sand culture experiments (data not reported here).

The genotypes were grown in soil culture in the pot under polyhouse condition at College of Horticulture and Forestry in the year 20182019. Plastic pots $(30 \times 25 \mathrm{~cm})$ were filled with $7 \mathrm{~kg}$ well-mixed sandy loam soil and treatment was given using $\mathrm{AlCl}_{3} \cdot 7 \mathrm{H}_{2} \mathrm{O}$. The soil has a pre-cropping value of organic carbon (1.5\%) (Walkley and Black, 1932), available nitrogen (100.8 mg/kg) (Subbiah and Asija, 1956) available phosphorus (19 $\mathrm{mg} / \mathrm{kg}$ ) (Bray and Kurtz, 1945), available potassium (120 mg/kg) (Hanway and Heidel, 1952) Exchangeable calcium and magnesium $(8 \mathrm{mg} / \mathrm{kg}$ and $2.4 \mathrm{mg} / \mathrm{kg}$, respectively)(Tucker and Kurtz, 1961) and Exchangeable $\mathrm{Al}(\mathrm{KCl})$ $(0.2 \mathrm{mg} / \mathrm{kg})$ (Barnhisel and Bertsch, 1983) before sowing. The pea crop was grown for three months the representative soil samples were collected, sieved through a $2 \mathrm{~mm}$ stainless steel sieve and kept in a plastic container and analyzed for the microbial population at Basic science laboratory, College of Horticulture and Forestry, Pasighat.

\section{Isolation and identification}

The classical serial dilution technique was used for isolation of total bacterial and fungal population from the soil sample by spread plate technique on appropriate media. Initially, the soil sample of 1 gram each was suspended in $9 \mathrm{ml}$ of sterile distilled water (water blank) and from this original suspension, further dilutions were made aseptically. For isolation of bacteria from soil, $10^{-5}$ dilution was finally selected. With the help of a sterile pipette, $0.1 \mathrm{ml}$ of the soil suspension was transferred from the final dilution to the sterilized Petri plate containing Nutrient agar (HIMEDIA) and the composition of media is given in Table 1 .

Fungi from the soil were also isolated in a similar manner. But here, $0.1 \mathrm{ml}$ of the soil suspension was transferred from $10^{-3}$ dilution to a sterilized Petri plate containing Rose Bengal Agar (HIMEDIA) and the composition of media is given in Table 2 . Then, the plates were incubated at $20-30^{\circ} \mathrm{C}$ for about 45 hours and the microbial populations were estimated as colony forming unit (cfu) $\mathrm{g}^{-1}$ soil on a dry weight basis. 


\section{Composition of the media}

$28 \mathrm{~g}$ of this was suspended in $1000 \mathrm{ml}$ distilled water and then boiled to dissolve the media completely. It was then sterilized by autoclaving at $15 \mathrm{lbs}$ pressure $\left(121^{\circ} \mathrm{C}\right)$ for 15 minutes. The solution was mixed well before pouring.

$31.55 \mathrm{~g}$ of this was suspended in $1000 \mathrm{ml}$ distilled water and then warmed gently to dissolve the media completely. It was then sterilized by autoclaving at $15 \mathrm{lbs}$ pressure $\left(121^{\circ} \mathrm{C}\right)$ for 15 minutes. The solution was mixed well before pouring into Petri plates.

\section{Results and Discussion}

\section{Bacterial Population (cfu/g soil)}

Averaged across Al treatment Matar Ageta-7 had the highest bacterial population (20.12 $\times 10^{5} \mathrm{cfu} / \mathrm{g}$ soil) which was at par with AP-3 $\left(18.03 \times 10^{5} \mathrm{cfu} / \mathrm{g}\right.$ soil) (Table 3$)$.

The bacterial population was found low in tolerant genotype viz. Kashi Samrath $\left(13.22 \times 10^{5} \mathrm{cfu} / \mathrm{g}\right.$ soil) and Kashi Samridhi $\left(13.00 \times 10^{5} \mathrm{cfu} / \mathrm{g}\right.$ soil). Due to Al treatment, the bacterial population increased from $10.72 \times 10^{5} \mathrm{cfu} / \mathrm{g}$ soil in control to $20.72 \times 10^{5}$ $\mathrm{cfu} / \mathrm{g}$ soil at $12 \mathrm{ppm}$ Al level. However, at 24 ppm Al level the bacterial population was
$16.89 \times 10^{5} \mathrm{cfu} / \mathrm{g}$ soil which was significantly lower than $12 \mathrm{ppm}$ Al level but significantly higher than control (Table 3 ).

Interaction between genotypes and $\mathrm{Al}$ was found to be significant for the bacterial population (Fig. 1). In the soil of susceptible variety viz. Matar Ageta-7 and AP-3 significant increase in bacterial population was observed at $12 \mathrm{ppm} \mathrm{Al} \mathrm{level} \mathrm{with} \mathrm{respect}$ to control.

However, there was no significant difference at $24 \mathrm{ppm} \mathrm{Al}$ level with respect to control. In the soil of tolerant genotype viz. Kashi Samrath and Kashi Samridhi there was no significant difference in the bacterial population at $12 \mathrm{ppm} \mathrm{Al} \mathrm{level} \mathrm{with} \mathrm{respect} \mathrm{to}$ control. However, at 24 ppm Al level significant increase in bacterial population was observed with respect to control.

\section{Fungal Population (cfu/g soil)}

The fungal population of soil was found highest in Kashi Samridhi $\left(3.43 \times 10^{3} \mathrm{cfu} / \mathrm{g}\right.$ soil) followed by Kashi Samrath $\left(2.58 \times 10^{3}\right.$ $\mathrm{cfu} / \mathrm{g}$ soil) (Table 3). Application of $12 \mathrm{ppm}$ $\mathrm{Al}$ in the soil doesn't have a significant difference in fungal population compared to control. However, at $24 \mathrm{ppm} \mathrm{Al}$ level fungal population significantly decreased with respect to control.

Table.1 Nutrient agar for bacteria

\begin{tabular}{|l|c|}
\hline Ingredients & Amount $\left(\mathrm{g} \mathrm{lit}^{\mathbf{- 1}}\right)$ \\
\hline Peptic digest of animal tissue & $5.00 \mathrm{~g}$ \\
\hline Beef extract & $1.5 \mathrm{~g}$ \\
\hline Sodium chloride & $5.00 \mathrm{~g}$ \\
\hline Yeast & $1.5 \mathrm{~g}$ \\
\hline Distilled water & $1000 \mathrm{ml}$ \\
\hline Agar & $15.00 \mathrm{~g}$ \\
\hline pH & $6.8-7.0\left(\right.$ at $\left.25^{\circ} \mathrm{C}\right)$ \\
\hline
\end{tabular}


Table.2 Rose Bengal agar with chlortetracycline for fungi

\begin{tabular}{|l|c|}
\hline Ingredients & Amount $\left(\mathbf{g ~ l i t}^{\mathbf{- 1}}\right)$ \\
\hline Peptone & 5.0 \\
\hline Dextrose & 30.0 \\
\hline Sodium nitrate & 2.0 \\
\hline Monopotassium phosphate & 1.0 \\
\hline Magnesium sulphate & 0.5 \\
\hline Rose Bengal & 0.05 \\
\hline Agar & 15.0 \\
\hline Distilled water & $1000 \mathrm{ml}$ \\
\hline Final pH (at $\left.\mathbf{2 5}^{\circ} \mathbf{C}\right)$ & $7.3 \pm 0.2$ \\
\hline
\end{tabular}

Table.3 Influence of $\mathrm{Al}$ on soil microbes

\begin{tabular}{|l|c|c|}
\hline Genotypes & $\begin{array}{c}\text { Bacterial } \\
\text { Population } \\
\left(\mathbf{1 0}^{\mathbf{5}} \mathbf{c f u} / \mathbf{g} \text { soil }\right)\end{array}$ & $\begin{array}{c}\text { Fungal Population } \\
\left(\mathbf{1 0}^{\mathbf{3}} \mathbf{c f u} \text { /g soil }\right)\end{array}$ \\
\hline Matar Ageta-7 & 20.12 & 1.24 \\
\hline AP-3 & 18.03 & 2.32 \\
\hline Kashi Samrath & 13.22 & 2.58 \\
\hline Kashi Samridhi & 13.00 & 3.43 \\
\hline C.D $(\mathbf{0 . 0 5})$ & $\mathbf{3 . 1 6}$ & $\mathbf{0 . 3 2 6}$ \\
\hline Al treatment & & 2.725 \\
\hline Control & 10.72 & 2.625 \\
\hline 12 PPM Al & 20.68 & 1.829 \\
\hline 24 PPM Al & 16.89 & $\mathbf{0 . 2 8 2}$ \\
\hline C.D. (0.05) & $\mathbf{2 . 7 3}$ & \\
\hline
\end{tabular}

Fig.1 Effect of $\mathrm{Al}$ on bacterial population $\left(10^{5} \mathrm{cfu} / \mathrm{g}\right)$ of soil, * indicates a significant difference with control [LSD (0.05) -5.47]

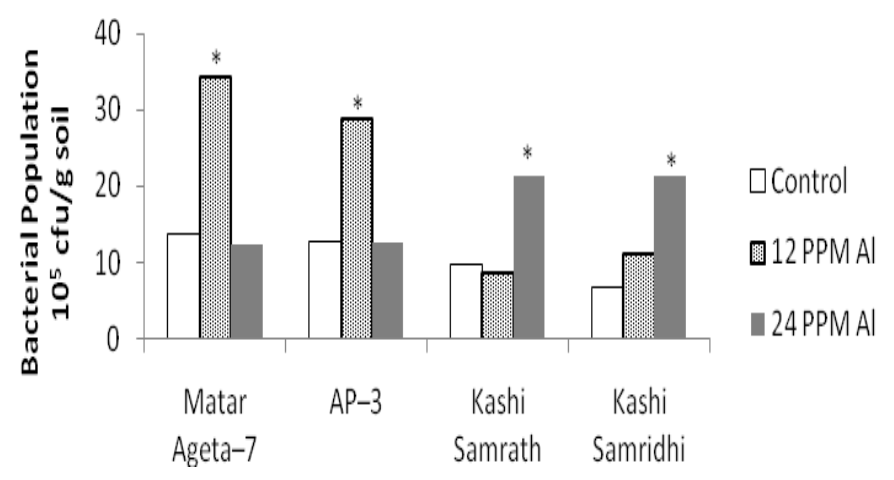


Fig.2 Effect of $\mathrm{Al}$ on the fungal population $\left(10^{3} \mathrm{cfu} / \mathrm{g}\right)$ of soil, * indicates a significant difference with control [LSD (0.05)-0.565]

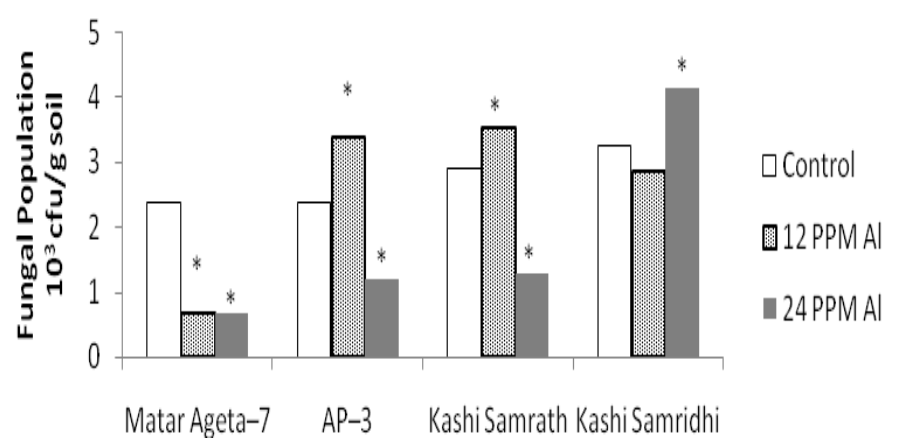

Interaction between genotypes and $\mathrm{Al}$ had a significant effect on the fungal population of soil. In control and $24 \mathrm{ppm}, \mathrm{Al}$ level fungal population was highest in the soil of Kashi Samridhi $\left(3.27 \times 10^{3} \mathrm{cfu} / \mathrm{g}\right.$ soil $)$ and $\left(4.15 \times 10^{3}\right.$ cfu/g soil), respectively (Fig. 2). However, at $12 \mathrm{ppm}$ Al level fungal population was found highest in Kashi Samrath $\left(3.53 \times 10^{3} \mathrm{cfu} / \mathrm{g}\right.$ soil $)$ (Fig. 2).

The bacterial population showed a positive relation with aluminium treatment. Low level of $\mathrm{Al}$ treatment showed an increase in the bacterial population in soil grown with susceptible genotype but at a higher level of Al the soil of tolerant genotype had a higher bacterial population. Joner et al., (2005) reported an increase in biomass of Grampositive bacteria and actinomycetes in the organic horizon of $\mathrm{Al}$ treated plots in forest soil. Guida et al., (1992) when studying aluminium toxicity towards Escherichia coli, found that growth inhibition was markedly dependent on $\mathrm{pH}$, recording sensitivity to 0.9 and $2.25 \mathrm{mM} \mathrm{Al}$ at $\mathrm{pH} 5.4$ and 6.6, respectively; aluminium toxicity increased when iron was omitted from the medium, which suggests that aluminium uptake involves iron transport systems, as previously reported (Davis et al., 1971). Accordingly, Gascoyne et al., (1991) found that some siderophore-producing alkalophilic bacteria were able to accumulate aluminium, as well as iron and gallium, from culture media. It has generally been easier to detect changes in soil chemistry and adverse effects of $\mathrm{Al}$ on aerial plant parts than to demonstrate $\mathrm{Al}$ induced stress symptoms on roots (Janhunen et al., 1995). A negative impact on microorganisms is frequently detected in vitro but is far more difficult to detect when working with indigenous microbial communities in soil (Illmer et al., 1995; Raubuch et al., 1999).

The fungal population reduced at a higher level of aluminium treatment. However, there was an increase in the fungal population of tolerant genotype Kashi Samridhi. Illmer et al., (1995) reported that the microbial biomass decreased with increasing aluminium concentration independent of the $\mathrm{pH}$. Not only plants are damaged by high concentrations of available $\mathrm{Al}$ (as is well known) but free living soil micro-organisms are inhibited too. The increase in fungal population in the rhizosphere of the tolerant genotype Kashi Samridhi may be due to the influence of excreted organic acid which neutralizes the $\mathrm{Al}$ in soil

From the present study, it was concluded that aluminium caused marked influence on the bacterial and fungal population in the soils grown with pea genotypes. The fungal population reduced at a higher level of aluminium treatment. However, there was an 
increase in the fungal population of tolerant genotype Kashi Samridhi. The bacterial population showed a positive relation with aluminium treatment. Low level of $\mathrm{Al}$ treatment showed an increase in the bacterial population in soil grown with susceptible genotype but at a higher level of $\mathrm{Al}$ the soil of tolerant genotype had a higher bacterial population. Further study is required to see the effect on different fungal and bacterial strain to find out the tolerant microbial strain. The exudation of organic acid is an external defense mechanism of legumes to neutralize toxic Al (Matsumoto and Motoda, 2012).

\section{References}

Barnhisel, R., and Bertsch, P. M. 1983. Aluminum. Methods of Soil Analysis: Part 2 Chemical and Microbiological Properties, 9, 275-300.

Bray, R. H., and Kurtz, L. T.1945. Determination of total, organic, and available forms of phosphorus in soils. Soil science, 59(1), 39-46.

Davis, W. B., McCauley, M. J., and Byers, B. R. 1971. Iron requirements and aluminum sensitivity of an hydroxamic acid-requiring strain of Bacillus megaterium. Journal of bacteriology, 105(2), 589-594.

Gascoigne, D. J., Connor, J. A., and Bull, A. T. 1991. Capacity of siderophoreproducing alkalophilic bacteria to accumulate iron, gallium and aluminium. Appl. Microb. Biotech, 36, 13641.

Guida, L., Saidi, Z., Hughes, M. N., \&Poole, R. K. 1991. Aluminium toxicity and binding to Escherichia coli. Archives of microbiology, 156(6), 507-512.

Hanway, J. J., and Heidel, H. 1952. Soil analysis methods as used in Iowa state college soil testing laboratory. Iowa agriculture, 57, 1-31.

Hartwell, B. L., and Pember, F. R. 1918. The presence of aluminum as a reason for the difference in the effect of so-called acid soil on barley and rye. Soil Sci, 6(4), 259-280.

Illmer, P., Marschall, K., and Schinner, F. 1995. Influence of available aluminium on soil micro-organisms. Letters in applied microbiology, 21(6), 393-397.

Janhunen, S., Palomäki, V., and Holopainen, T. 1995. Aluminium causes nutrient imbalance and structural changes in the needles of Scots pine without inducing clear root injuries. Trees, 9(3), 134-142.

Joner, E. J., Eldhuset, T. D., Lange, H., and Frostegård, A. 2005. Changes in the microbial community in a forest soil amended with aluminium in situ. Plant and soil, 275(1), 295-304.

Joner, E. J., Johansen, A., Loibner, A. P., dela Cruz, M. A., Szolar, O. H., Portal, J. M., \&Leyval, C.2001. Rhizosphere effects on microbial community structure and dissipation and toxicity of polycyclic aromatic hydrocarbons (PAHs) in spiked soil. Environmental science and technology, 35(13), 2773-2777.

Marschner, P., Yang, C. H., Lieberei, R., and Crowley, D. E. 2001. Soil and plant specific effects on bacterial community composition in the rhizosphere. Soil biology and biochemistry, 33(11), 14371445.

Matsumoto, H., and Motoda, H. 2012. Aluminum toxicity recovery processes in root apices. Possible association with oxidative stress. Plant Sci., 185: 1-8.

Raubuch, M., Lamersdorf, N. P., and Bredemeier, M. 1999. The impact of reduced atmospheric depositions on soil microbial parameters in a strongly acidified Norway spruce forest at Solling, Germany. Journal of Plant Nutrition and Soil Science, 162(5), 483491.

Schallmach, E., Minz, D., and Jurkevitch, E. 2000. Culture-independent detection of 
changes in root-associated bacterial populations of common bean (Phaseolus vulgaris L.) following nitrogen depletion. Microbial ecology, 40(4), 309-316.

Slawson, R. M., Van Dyke, M. I., Lee, H., and Trevors, J. T. 1992. Germanium and silver resistance, accumulation, and toxicity in microorganisms. Plasmid, 27(1), 72-79.

Subbiah, B. V., and Asija, G. L. 1956. Rapid procedure for the estimation of the available nitrogen in soils. Current Science, 25, 259-260.

Tucker, B. B., and Kurtz, L. T. 1961. Calcium and magnesium determinations by
EDTA titrations. Soil Science Society of America Journal, 25(1), 27-29.

Walkley, A., and Black, I. A. 1934. An examination of the Degtjareff method for determining soil organic matter, and a proposed modification of the chromic acid titration method. Soil science, 37(1), 29-38.

Wilkinson, S. C., Anderson, J. M., Scardelis, S. P., Tisiafouli, M., Taylor, A., and Wolters, V. 2002. PLFA profiles of microbial communities in decomposing conifer litters subject to moisture stress. Soil Biology and Biochemistry, 34(2), 189-200.

\section{How to cite this article:}

Mohd Talha Ansari, Pranabjyoti Sarma, A. S. Mailappa, C. Deo, A. K. Singh, L. Wangchu and Hazarika, B. N. 2021. Rhizosphere Microbial Population of Pea Genotypes under Different Level of Aluminium. Int.J.Curr.Microbiol.App.Sci. 10(02): 3023-3029. doi: https://doi.org/10.20546/ijcmas.2021.1002.331 